\title{
El Popol Vuh, expresión y sumario del sentido ético fundamental
}

\author{
Angel Morán, \\ Centro de Reflexión Teológica, \\ San Salvador.
}

En un artículo anterior' hemos analizado las diversas interpretaciones del Libro sagrado k'iche'. Queremos analizar en este artículo cómo aparecen los valores élicos en cada una de las interpretaciones.

1. Clarificación y evaluación de los valores éticos en las diferentes interpretaciones

\subsection{La interpretación biblico-cristiana}

En la interpretación bíblico-cristiona se buscó una respuesta en clave bỉlico-teológica a la interrogante del oriente hemos venido, de más allá del mar, con frecuencia repetido en el lexto. En la explicación estaban incluidos problemas con visos dogmáticos a los cuales los evangelizadores se creyeron obligados a dar solución, por ejemplo, el monogenismo. Juntamente con esta cuestión, debido a las semejanzas plurales con la cuestión bíblica que habían descubierto, bullían en su mente muchas preguntas sin poder darles respuesta, pues en su época no existía la milología científica, ni la antropología, ni la elnología, ni la historia de las religiones, ni otras ciencias humanas.

Ante sus ojos llenos de pasmo aparecía un Antiguo Teslamento de los maya$k$ 'iche's con su pecado original, con un éxodo lleno de sufrimientos y penalidades, partiendo del oriente hacia una tierra desconocida, el paso de un mar "ber-

1. "Etica y religión en algunas culturas mesoamericanas. Diversidad de interprelaciones", Revisfa Latinoamericana de Teología, 51 (2000), pp. 265-291. 
mejo", con la división de las lenguas y la dispersión de las tribus, con la llegada a una tierra de promisión, anunciada por los dioses.

El fraile dominico F. Ximénez. descubridor del Popol Vuh, junto con sus compañeros de misión, halló, asombrado, todas estas cosas y muchais olras verdades de nuestra sacrosanta religión en el Libro k'iche', sin sospechar que eran unas consiantes, pertenecientes al acervo élico-religioso de los pueblos de la humanidad: salir de las manos de la divinidad (oriente. pais de la luz y de la vida), peregrinar y, al final del itinerario existencial, regresar al lugar de los dioses, simbolizado en la antigua y célebre frase exitus el reditus. El horizonte élico, sin asomarse a él de una manera consciente, lo están entreviendo estos primeros mensajeros implícitamente: un pueblo, como tantos otros, como el mismo pueblo hebreo, azuzados por el impulso de la marcha hacia la propia humanización, peregrinan buscando espacios y hábirurs que les permitan un mejor desarrollo del que actualmente tienen.

En esa marcha se va realizando dolorosamente su propia organización tribal, política y religiosa. Los obstáculos externos quedan simbolizados por pasos de mares rojos y de luchas épicas con los que se oponen a la invasión de sus propios territorios. Y al mismo tiempo se va tejiendo la urdimbre de la cultura y de la historia con las tradiciones que van entregando a la memoria de la coleclividad, por medio de mitos o símbolos rituales o grabando en pieles de animales u otros materiales diversos para que no caigan en el olvido. En medio de obstáculos internos surgen las desavenencias, los odios, las luchas fratricidas, la división de las lenguas por no querer entenderse, $y$ la dispersión de las familias tribales. Todo esto aparecía ante los ojos de los misioneros, lectores y traductores del Códice $k^{\prime} i c h e^{\prime}$ y de sus comentaristas, aunque sin poderlo comprender a cabalidad, pues para ellos la única explicación posible es que se tratase de una interpolación de la Biblia.

El hombre, sin embargo, con su doble dotación natural, congénita y adquirida en la diversidad comunitaria, se torna en receplor de un caudal que le ha sido legado y en creador de obras. Lo que el hombre crea en la esfera material, social y espiritual, es la cultura: instrumentos, instiluciones familiares y estatales de poder y de gobierno, sistemas económicos y políticos, métodos de educación o enseñanza, costumbrismo popular, arte, religión. Todo ello constituye la dimensión ética, como realidad inlramundana. $Y$ cuando este contenido del quehacer humano es traspasado por una cosmovisión creyente, se pone de manifiesto la ética religiosa. La simbólica del camino pertenece a lo estructural del hombre, sea religioso o puramente humanista o secularizado: salir y marchar en la búsqueda de algo mejor, siempre más allá, hacia la plena humanización, traspasando montes, ríos y mares, divisiones y luchas, símbolos de las penalidades sin término que les esperaban en su caminar. 
Al del oriente hemos venido, de más allá del mar, reiterado en el texto, intentaron responder de otra manera otros comentaristas. No movidos por razones religiosas, sino desde una perspectiva profana y puramente cultural, y no encontrando en la fe de los indigenas la verdadera causa que pudo generar esas expresiones en el texto aborigen, culparon a los evangelizadores de haber inducido a los autóctonos a distorsionar y corromper sus auténticas tradiciones con las doctrinas y enseñanzas bíblico-cristianas misioneras. En el empeño de csios estudiosos por lograr el texto originario y racial de las tribus aborígenes mesoamericanas se muestra un claro empeño, legítimo y tolalmente ético.

Las dos posturas que hemos mencionado lenían en común que ambas hablaban de influencias biblico-cristianas, y en ello residía también el error de las dos. Las semejanzas no se pueden concebir como concordancias e influencias bíblicas por el mero hecho de que coincidan con pasajes de la Biblia, pues brotan de un hontanar más profundo e inmediato que un libro (por muy sagrado que éste sea), del cual se puedan copiar: lodos esos milologemas Пluyen de la realidad estructural y óntica del ser humano, que asi lo construyó el Misterio, como lo llama la fenomenología de la religión.

\subsection{La interpretación etno-geográfica}

La teoría etno-geográfica, por su parte, afronló, aunque con otro lenguaje, esla misma cuestión: de dónde procedieron y cuál fue su familia racial. Las razones y respuestas que se presentaron, dejando atrás lo aducido en la anterior interpretación por no tener base científica, fueron profanas y bien fundamentadas científicamente. La respuesta al problema de los origenes y del entronque racial de los mesoamericanos y de los restantes pobladores del nuevo mundo fue incumbencia de los antropólogos, etnólogos y arqueólogos posteriores, cuando, bien pasada la mitad del siglo XVIII, fueron encontradas las ruinas de Palenque'. Obviamente, ese descubrimiento no estuvo, ni podía estar, al alcance de los misioneros, aunque alguno de ellos tuviera intuiciones felices sobre el problema, debido a su observación de la tipologia de los indigenas en las diversas regiones por donde anduvieron?'

Los estudiosos de esta fase cienlífica han logrado adquisiciones teóriciss sólidamente basadas, y van siendo poco a poco admitidas por la mayor parte de los antropólogos y culturólogos: la procedencia asiática y los varios orígenes raciales de las familias indígenas americanas. La cuestión etno-geográfica sigue

2. Cfr. M. Ballesteros Gaibrois, Culura y religión de la América prehispánica (Madrid, 1985), p. 35. Las ruinas fucron localizadas a mediados del siglo XVIIl por cl párreco cspañol de Palcnque. Hasla 1784 no sc prestó alcnción al hallazgo.

3. Cfr. B. Cobo, Historia del nuevo mundo (primcra edición en M. Jiméncz de la Espada, Scvilla), pp. 1890-1895; lambićn J. Acosta, Hisioria natural y moral de las In. dias, (original de 1590; México, 1960). 
abierta, pero los eruditos continúan en su esfuerzo con la esperanza que han suscitado los medios técnicos modernos para conseguir algún día la respuesta completa al problema.

Es importante caer en la cuenta de que los indígenas consideran un derecho primordial poseer una lierra por patria y no ser vistos como desarraigados y apátridas; lodo ello pertenece a la dignidad de la persona. Además, desde su cosmovisión religiosa, esta misma dignidad se consideraba engrandecida y profundamente sentida, en cuanto emparentada con la divinidad: del oriente hemos venido, de más allá del mar, del país de sol, de la luz y de la vida, de la tierra de los dioses. Aquí hay que recordar cómo, buscando la misma dignidad del hombre, el pensamiento occidental, con santo Tomás de Aquino a la cabeza, examina y analiza la imago Dei como lundamento de esa dignidad. Posteriormente, también el humanismo del renacimiento, por otras razones y no en abierla exclusión del espíritu cristiano -pues también lo hizo la teología del siglo XVI-, enfoca la causa del hombre convirtiéndola en verdadera calegoría manifestadora de la dignidad del mismo hombre .

\section{La interprelación histórico-etno-cultural}

La cultura -con ser también ella una derivación de la humanización- se muestra luego como una matriz universal de donde brotan incalculables valores morales, que comportan la realización personal del ser humano y establecen un ideal dinámico válido y ansiosamente apetecido por los poseedores de esa determinada cultura. La hipótesis histórica etno-cultural ha pretendido medir el alcance de la cultura maya-k'iche" desde el contenido que se expresa en el Popol Vuh. El interrogante es si éste es un reflejo y suma de la cultura panmaya o está circunscrito a la civilización k'iche". No estimamos inconciliables las dos posturas. Abandonando la fijación en las propias pruebas y no otorgándoles una excesiva ponderación, parecen no ser decisivas ni las pruebas etnográficas ni las literarias internas: la comprensión universalista no puede prescindir del contexto local, pues se mostraría desencamada, sin corporalidad, expuesta a la fantasía y a volatilizarse; ni la comprensión restringida y localizada puede cerrarse sobre sí misma, porque la comprensión popolvujiana resultaría inadecuada, empequeñecida, y a fin de cuentas, distorsionada.

En ese escenario más limitado y restringido pudieron estar asentados en un tiempo los mayas clásicos, como en una parle geográfica de un territorio mucho más amplio de sus dominios, conservado o modificado posteriormente por los actuales k'iche's, con cambios topográficos por modificaciones agrícolas y por la edificación de monumentos de centros ceremoniales. De esas transformaciones lopográficas a base de gigantescos esfuerzos, tenemos ejemplos en culturas

4. Cfr. M. Vidal, "La moral como servicio a la causa del hombre”, Moralia 45 (199()), pp. 3-29. 
aborígenes en México y Perú, que no vamos a mencionar ahora. Los k'iche's, como se consignó antes, recibieron un legado de sus antepasados, y, dada la idiosincrasia indígena, sin duda, trataron de conservarlo; pero han sido también creadores dentro de la herencia recibida. Al cabo de muchos centenares de años después de que palideció la estrella de la civilización maya, no es fácil a veces señalar con rigor lo que pertenece al legado y lo que es creación de las nuevas generaciones autóctonas.

\subsection{La interpretación fllosoffico-antropológica}

La perspectiva filosófico-antropológica estudió y analizó la cultura y el pensamiento -en sí mismos y desde sí mismos- de estas tribus de Los Allos de Guatemala, y llegó a resultados interesantes. La tendencia posilivista sostiene que en el Popol Vuh el hecho religioso conslituye un mecanismo elicaz y complejo de integración político-social. En manos de las minorías gobernanles, es erigido en sistema de control sobre la colectividad plebeya mayoritaria, de soporte y de legitimación del poder y de la actuación de las élites, de profundización y persistencia de desigualdades en la sociedad indígena.

Se le concede a la religión un papel prolagónico como única ideología advertida y tolerada por las masas. La religión se torna en fundamento de derecho y de moral, y se convierte en transmisora de valores y pautas de comportamientos, sancionados por poderes "sobrenaturales". Fue, así, el factor fundamental que hizo posible el acceso de las comunidades mayas a la civilización y a la cultura. Es la religión convertida en ideología legitimadora, cohesiva y sancionadora del orden civil, con la misión principalísima de justificar y perpetuar las desigualdades entre los miembros de la colectividad aborigen". Se volvió hasta tal punto coincidente con su función social en lo profano, que se llegó a identificarla, reductivamente, con esta función.

Según esta tendencia, la religión popolvujiana vendría a quedar reducida a una audaz y espléndida elucubración de los sabios, sacerdotes y gobernantes mayas para apoderarse de to desconocido por la aclividad de la inteligencia humana, y a una función legilimadora de su dominio sobre la coleclividad de las tribus. Parece no reconocerse y apreciar algún contenido sobrehumano existente más allá de la realidad mundana, astral y cósmica. Ni el ámbilo de lo sagrado, ni la realidad transcendente de la divinidad, ni de las actitudes y vivencias del sujeto religioso tendrían consistencia real. no serían nada: "el ámbilo de la vida religiosa es un prodigioso depósilo de representacioncs, pero éslas no son nada específico"'. Esta-interpretación del hecho religioso opla por un humanismo que,

5. Cfr. M. Rivera Dorado, La religión maya (Midurid, 1986), p. I6.

6. C. Levy-Siraus, L'homme mi (París, 1971, cil. por J. Ries): "C. Levy-Siraus", cn P. Poupard (cd.). Diccionario de las religiones (Barcclona, 1987), p. 985. 
al destacarlo incisivamente, parece adoptar la posición atea. Se declara divergente y opuesta a la dimensión religiosa.

Ante la cerrazón de esta opción habría que decir abierlamente que la religión y el hecho religioso no huyen de la mirada suspicaz de la razón, ni se sustraen del examen crílico de la misma; sus exigencias son reconocidas y realmentc cumplidas. Mas la religión reivindica, asimismo, que se le reconozcan sus legítimos derechos: que se la tome por lo que es y como es, sin alterarla ni ralsearla, que se la juzgue desde si misma. El camino que han intentado scguir los estudiosos humanistas imparciales y filósofos de la religión es el de no tralar de oponer dos órdenes de verdades, el de la razón y el de la religión —destacando la diferencia de mélodos de aproximación a la misma realidad_, sino el de sustituir el dualismo de la verdad o el de la realidad por la dualidad de perspeclivas o vías de acercamiento a la misma realidad. En su reflexión crítica sobre la religión, el filósofo intentará comprenderla y el teólogo tratará de entender las exigencias de la razón, como purificación y callársis de las actitudes que integran el complejo hecho religioso'.

Por su parte, la tendencia de signo espiritualista de la perspecliva filosólicoantropológica enfatiza la mentalidad sacral de cste pueblo aborigen, aunque sin pasar por alto otras dimensiones, como son la comunitaria y la político-social. Sin reticencias, se ponen de relieve los aspectos religiosos de las historias y tradiciones popolvujianas, que pueblan las páginas del texıo. El discurso filosófico de esta lectura se adentra por los problemas existenciales y eternos que agobian universalmente a todo hombre y que sc expresan preocupantes en cl Popol Vuh: el de dónde hemos venido, para que estamos en la vida, y después a dónde tenemos que partir. No se queda en la visión de la floresta literaria. ni tampoco se aventura a caminar por esquemas filosóficos, ni a tejer sistematizaciones ideológicas ajenas al Libro. El fenómeno sacro pertenece a la realidad mundana y humana, y lo que primero aparece en él es la dimensión natural, autónoma y regida por sus propias leyes, reconocida y afirmada por las dos tendencias de la perspecliva filosófico-antropológica.

Por otra parte, para la leclura naturalista, el hecho religioso en su conjunto no posee ninguna olra realidad más que la mundana, y su proyección queda enteramente confinada dentro del ámbilo mundano. Para entenderlo y explicarlo no hay que acudir a olras inslancias y recursos que a los humanos: la psicología. la sociología, la etnología, la política, la economía, y siempre - todo ello— bajo el dictado de la razón. Para la opción de signo espiritualista, esto supone una reducción de valores y una negación de la dinámica de la misma razón, que es la

7. Cfr. J. Martin Velasco, Introduccion a la fenomenología de la religión (Madrid, I94.1). pp. 189-196: M. Neusche, "Religion (filosofía de la )". en P. Poupard (cd.). Diccionsario de las religiones (Barcelona, 1487), pp. 1502-1505. 
de mantenerse siempre abiera y en incansable búsqueda de insospechados horizontes de la realidad. Las deliciencias y fallas de la religión no deslegiliman ni invalidan ni anulan el fenómeno religioso en sí mismo, ni cercenan, por otro lado, los impulsos de la razón para llegar hasta donde pueda. Aquéllas son comprensibles e hislóricamente explicables en las elapas en que se encontraban la sociedad y la cultura maya-k'iche'.

\subsection{La comprensión poético-literaria}

La explicación poético-literaria pretendió dilucidar en las producciones de la literatura aborigen maya-k 'iche', en especial del Popol Vuh, las formas narrativas en que se encuentra consignado el pensamiento y estilo de su cultura. Llega a la conclusión de que la obra escrita incluye varias formas y géneros literarios, desde el verso pareado hasta la composición mítico-histórica, épica, legendaria y fabulosa con las que se reseñan los fastos cronísticos de su arcaica y actual existencia terrena, "iniciándolas desde que fueron formadas todas las cosas y se establecieron sus fundamentos. Diremos luego lo que hizo el pueblo Quiché" (PV 1-2 y 892). Toda esta pluralidad y variedad de expresión no conducen al desorden, ni a la confusión, ni al irrealismo, sino a la diferenciación y a la riqueza narrativa.

Al leer el Libro con atención y detenidamente se pueden detectar en él la frescura y la ingenua espontaneidad de un pueblo joven que relata los evenlos de su historia, los sufrimientos de su existencia, la celebración de sus cultos, juntamente con las plegarias a sus dioses, con plena sencillez e inmarchito candor, que, a veces, parece deslizarse hacia un deje infantil, según el sentir del hombre actual. No vamos a extendernos ahora en los abundantes y notables valores éticos y en las más variadas expresiones artísticas de esta cultura, como pintura, música, elaboración de hilados de algodón con rica combinación de vivos colores de tintura vegetal, finos tejidos de plumas de ave, artística manufactura de objetos de barro, preciosos objetos de adorno hechos de jade. En el ramo de la arquitectura, aunque sus edificaciones no alcanzaron la dignidad majestuosa y el gusto refinado de las construcciones clásicas mayas, sin embargo, el Libro (PV 801) y los cronistas nos hablan de construcciones y edificios de cal y canto, en esta época. La vivienda popular indígena quicheana muestra un gran parecido con la vivienda maya.

La exploración y divulgación de la herbolaria medicinal, la elaboración de una especie de papel, hecho a base de la corleza de algunos árboles, donde pintaban y grababan sus tradiciones y leyendas, la fiesta costumbrista, realzada con música y actuaciones teatrales y mímicas, son manifestaciones cargadas de múltiples valores éticos. Sin llegar a la altura de sus antepasados, poseyeron un conocimiento absiraclo grande del cómputo matemático y de la medición del liempo, elaborando el calendario Tzolkin, imitación y herencia del famoso calendario maya, que, aún hoy, es seguido en Guatemala y consignado con exactitud 
en agendas para uso popular, sobre Iodo entre los indígenas. Pero lo que ha causado mayor admiración entre los estudiosos son sus logros literarios, míticohistóricos y religioso-morales, que en este artículo hemos tratado de examinar, por lo que no vamos a insistir más en ello.

\subsection{La interpretación político-social}

La lectura políico-social, con sus tres variantes, ha descubierto contenidos relativamente novedosos por lo poco conocidos y por inesperados. La primera llegó a descubrir la realidad física, geográfica, polílica y social de Xibalhấn , más allá de la oscura imprecisión del milo. Las dos perspectivas restantes muestran contenidos no fácilmente advertidos, por estar ocultos en el subsuelo del texlo popolvujiano y que, sólo con perspicacia, son exhumados por ellas. Se podrían hacer puntualizaciones valorativas sobre algunas de sus afirmaciones que parecen no ser exactas por una insuficiente comprobación histórica y por su excesiva insistencia en devaluar la dimensión ética de las tradiciones religiosas y mílicas del Códice k'iche'. Una de las afirmaciones proclama: "el principal sostén del señorío k'iche" fue la religión, su principal arma de dominio"'s. Quede admitida la posibilidad, mas no parece segura. Los sacrificios humanos en que se prelende basar esta afirmación fueron, con toda probabilidad, un episodio transitorio, detestado por la comunidad indigena e impuesto por dominadores foráneos.

El reducir el lexto consignado en el Libro a una legitimación del pueblo k'iche' y de la autoridad de sus gobernantes, sin más precisiones, y con la total connivencia de la tradición y del mitógrafo, que nos entrega en su obra, no es fácil aceptarlo. Puede preguntarse si con ello no se busca un funcionalismo en que apoyar la teoría propuesta. Como valor que se deriva de esta opción es importante recordar la adaplación del pasaje mitológico del opulento Vucub Caquix (PV 84-207) al proceso actual de liberación del pueblo indigena con el desenmascaramiento de tantos opresores del poder y de la riqueza de hogaño, como el Vucub Caquix de los tiempos primordiales.

\section{Deficiencias y límitaciones de la dimensión ética}

Para finalizar trataremos de señalar las deficiencias y limitaciones de la dimensión ética y establecer un balance comparativo con los valores morales que hemos considerado hasta ahora, manifestados todos en el Popol Vuh. Las limitaciones las agnuparnos en los apartados que siguen.

8. Xibalbó es en la escatología mesoamericana el mundo subternáneo, el lugar de las sombras, de la muerte, el sitio de los demonios, de los enemigos de la luz y de la vida.

9. Cfr. H. Cabezas, "Los señorios quichés: un intento de interpretación", en R. M. Carmac y F. Morales Santos, Nuevas perspectivas sobre el Popol Vuh (Guaternala, 1983), p. 36. 


\subsection{Las creencias}

Los principales dalos que incluimos en las creencias se refieren a la divinidad con sus atribulos, providencia deífica en la vida de los creyentes y en las promesas de vida elema, en el reino futuro. Las divinidades popolvujianas, como se muestran en el Libro, son politeislas, manifestándose dualislas y con frecuencia monislas. El Ser supremo que las aglutina no puede impedir su politeísmo, al tener que acudir los creyentes en sus necesidades a otros dioses más cercanos, de quienes recaban su ayuda y prolección.

El dualismo con la doble cara de deidad benéfica y maléfica atenta esencialmente contra la realidad iranscendente del Misterio, en cuanto que el bien y el mal quedan inscritos y confundidos en la misma esencia divina, eliminando la diferencia entre el bien y el mal, y haciendo imposible al sujeto religioso el reconocimiento de la total supremacía de la divinidad y la completa distinción en su conciencia y en la realización de su fe entre lo que es bueno y lo que es malo.

El monismo popolvujiano introduce al Misterio en el panteísmo, ya que el mundo creado, el sujeto religioso y los dioses, quedan envuelios en la misma realidad, cayendo en una concepción antinómica de la divinidad. Los atributos de las deidades quedan envueltos en la misma línea de contradicción, siendo al mismo tiempo perfeclos e imperfectos, buenos y malos, lodopoderosos que fracasan en sus creaciones, omniscientes y sincrónicamente equivocados, inmortales y necesilados de que los hombres los alimenten con la sangre y con sus corazones para no fenecer.

La providencia deifica en la vida de sus fieles creyentes resulta generalmente incierta al no conocer de antemano la actitud benévola o maléfica de la divinidad por la dualidad de la misma, ni el tiempo propicio o desfavorable para esperar su protección, y en todo caso, queda reducida a una ayuda o amparo temporal, no incondicionado y perpetuo, pues los dioses están necesitados de sus fieles, lo mismo que éstos sienten la necesidad de las deidades. La necesidad que tiene la divinidad de la comunión vital existencial con los humanos para poder subsistir quiebra la eternidad y transcendencia del Misterio y lo torna limitado y temporal. Las promesas de vida eterna en el reino futuro, hechas por los dioses a sus fieles, no sobrepasan la temporalidad, que sigue aun después de la muerte, aunque ya no se den sufrimientos, sino sólo paz y bienestar.

Visto desde la razón, la religión expuesta en el Libro k'iche' no acertó a formular, en la zona de las creencias, la configuración de sus divinidades con sus atributos y promesas de la vida futura para sus adeptos. La concepción popolvujiana de la realidad absoluta y divina, vista objetivamente, logra con dificultad mantenerse en pie por lo imperfecta y paradójica. Sin embargo, el hecho de que la concepción k'iche' haya intentado conferir un carácter tetsta y ultramundano a sus dioses, como realidades supramundanas que crean el universo y lodas las cosas existentes en el mundo, no tomando a éstas como producto de 
ningún hacedor terreno o de la casualidad o del fatalismo, está señalando, como valor ético, su empeño de entrar en el ámbito de la razón, atisbando la apertura existencial del hombre a la transcendencia, apertura que hace que el hombre se reconozca como lo que es, ser finito, no acabado.

Lo que se proclama no es la respuesta adecuada, ni adecuadamente formulada, pero sí la respuesta a una pregunta inarticulada, balbuciente, que siempre intenta y busca expresar lo que es inexpresable e inasible. $Y$ hay que recordar que la fe no puede estar enteramente vinculada a una formulación doctrinal. La formulación de la doctrina no es la fe. No hay formulación adecuada de la fe. Los dogmas y demás fórmulas de fe son medios o cauces por los cuales transita la fe. Entre doctrina y fe no sc pucde dar unicidad, ni identidad.

Si desde el ángulo de la razón aparece la contradicción interna en la configuración de las deidades popolvujianas, esa claridad no aparece desde la vivencia de los creyentes indígenas, puesto que, al proponerles los evangelizadores el anuncio del Dios cristiano, con prontitud y sin reticencias lo fueron aceptando. Prueba esto que en la experiencia sentida y vivida de la divinidad de su tradición indígena no se daba una lejania insalvable entre ésta y el Dios cristiano, tan acentuada como lo podría indicar la razón; ni que los aborígenes no se detuvieron a pensar en los dilemas en que se hallaba envuelta la configuración dada a sus dioses. Es explicable que en el nivel de recreación interior de la fe, donde tiene lugar la vivencia personal, íntima o mística de la divinidad, quedaran difuminadas o borradas las discrepancias que cobran tanto relieve en el plano de la reflexión.

La existencia de la otra vida, sin lograr el acierto de concebirla y expresarla razonablemente, está mostrando una aproximación entre el pensamiento biblicocristiano y la tradición indígena"', que confiesa que las realidades últimas y definitivas ínsitas en el hombre no pueden quedar clausuradas en lo transitorio y perecedero de lo intramundano.

\subsection{El kerigma, el anuncio y la enseñanza de las creencias}

Otro de los datos principales de la fe en cualquier religión es la comunicación o enseñanza de las creencias que se profesan a los que las ignoran. En el Popol Vuh no se encuentra ningún pasaje que exprese y directamente haga refe-

10. Los K'iche's conceptúan la felicidad cterna, de la otra vida, como un descanso bajo una frondosa ceiba. Este mismo símbolo-mito lo encontramos en una lápida scpulcral cristiana de las calacumbas de Domitila, en Roma, de finales del siglo tercero. Esta figura bucólica de origen pagano se utilizó desde el comienzo por los cristianos como símbolo del descanso y de la felicidad eterna, que el alma del difunto encuentra en la otra vida. Este símbolo ha sido reproducido en el logotipo de la portada y de la página quinta de la edición española del Calecismo de la Iglesia casólica. 
rencia a este punlo. No existía ningún centro especial, como el Calmécacriahuall, en que se diera adocırinamiento religioso, ni maesiros encargados de hacerlo. La instrucción se recibía en el grupo farniliar, quedando reducida a unia formación moral, hecha mediante el relato de mitos y leyendas como las de Hun Ahpú e Xbalanqué (PV 208-539) y la de Vucub Caquix (PV 84-207), a la cual se añadía la enseñanza de normas provenientes de la ejemplarización existencial de los mayores desde tiempos arcaicos, contenidas en el llamado por Estrada Monroy heptálogo indigena". Sc puede afirmar que la doctrina de tipo dogmático tenía para los k'iche's mucha menor importancia que la docirina moral.

El conjunto de oraciones a las divinidades relleja, asimismo. el acopio de la docirina que poseían acerca de la religión, y es en estas observancias oracionales donde se pone de manifiesto su concepción politeísta. Las plegarias aparecen dirigidas primeramente al Ser supremo, Huracán, Corazón del Cielo y de la Tierra. Al final de las plegarias son nombradas las deidades que componen la corte celeste de Aquél (PV 582-583, 865).

\subsection{El culto}

Cuatro eran las cosas que los aborigenes anhelaban conseguir de los de Arriba: vida terrena larga, salud corporal, tener hijos y el mantenimiento para pasar la vida. Para la consecución de estos deseos practicaban diversos ritos sacrificiales, desde el derramamiento de la sangre propia hasta la inmolación de víctimas animales en el altar'?. Entre las peticiones se hallan también cosas más espirituales como las buenas costumbres, la superación de las pasiones: "que no forniquen ni sean juzgados ni condenados en ningún consejo" (PV 865), la paz y la concordia. Se manifiesta la condición humana, agobiada por las necesidades inmediatas. La plegaria más frecuente e insistente es la oración de petición: menos habitual y en tono menor se da la acción de gracias y alabanza. En el culto, como ya se ha señalado, se presentó, en alguna época de la historia del pueblo quicheano, el problema de los sacrificios humanos, pero pensamos que esto ya ha sido suficientemente explicado.

\subsection{Las actuaciones y comportamientos en la vida práctica}

En el conjunto de verdades dogmálicas de uná religión (del griego dokeo, en su significación básica de "lo que ha aparecido como verdadero") el comportamiento en la vida práctica es fundamental y exigencia absoluta para el creyente. Si el acervo de verdades se presenta confuso, indelinido y contradictorio, la obligatoriedad, emanada de esas verdades, adolecerá para el creyente de lo mismo. Por ello, la esencia de los principios dogmáticos no se puede poner sola-

11. Cfr. A. Estrada Monroy, Vida esotérica Maya-K'ekchi (Gualemala, 1993), pp. 80)-81.

12. Cfr. Román Hierónimo, Repúblicus del mundo (Salamanca, 1558), pp. $125 \mathrm{s.}$ 
mente en el concepto abstracto de la comunicación revelatoria divina de una verdad, sino que se ha de colocar en lo que ha dicho e impuesto Dios fácticamente al hombre por medio de sus enviados, por medio de Cristo. De esas verdades dogmáticas se derivan las obligaciones claras e inconfundibles, que se han de plasmar en las actitudes y los comportamientos del hombre libre religioso.

En el cristianismo, el cúmulo de principios dogmáticos, claros y decisivos aparece deducido de la revelación en el kerigma bajo sus dos formas, el dirigido a los paganos y el dirigido a los judios, y un poco más tarde, en las fórmulas fijas de los símbolos o credos. En el kerigma a los paganos se anuncia la existencia de un solo Dios verdadero, creador del cielo y de la lierra, y a quien es absurdo equiparar a objetos materiales, como ídolos o estatuas, de los que se han de apartar para volverse al Dios vivo y servirlo, como lo proclama Pablo en su discurso de Listra (Hch 14, 15-17) y en el del areópago de Atenas (Hch 17, 22s). En el dirigido a los judíos, se conserva el mismo kerigma, hasta llegar a relacionarlo con Cristo y culminar en él, muerlo, resucitado, sentado a la derecha del Padre y Señor de la historia, juez de vivos y muertos y cuyo reino no tendrá fin, como en el discurso del apóstol a los paganos, en Antioquía de Pisidia (Hch 13, 16s).

Al faltar esta precisión y definición en la religión quicheana, aparece una doble ambigüedad dogmática y ética, que incide seriamente en toda la existencia del homo religiosus de la tradición k'iche'. Se presenta éste prosternado ante las representaciones teriomórficas de los ídolos, derramando su propia sangre y la de sus víctimas, diciendo sus plegarias lleno de lágrimas y fervor religioso con el rostro levantado hacia el cielo (PV 863-866). Se encuentra poseído por el temblor, la angustia y la incertidumbre ante la presencia de las divinidades a las que, queriendo aplacar, entrega su misma persona y la destruye, inmolándose hasta el exceso, en el ser-únicamente-para-los-dioses y para-la-comunidad. Salido de las manos divinas tiene, sin embargo, una conciencia muy viva de pecado. Ante el más allá de la muerte, no acierta a suscitar en si la esperanza, sino que crecen desmesuradamente su angustia e incertidumbre de creyente ${ }^{13}$.

\section{Inculturación: el reino de Dios y los valores religiosos k'iche's}

En la doctrina y en la moral del creyente cristiano, al menos en la teoría, se dan claridad, definición y totalidad en los principios que lo conducen a la seguridad en la fe y en su conducta ética y a la posesión de la esperanza, frente a lo que lo aguarda más allá de esta vida. A pesar de lo dicho sobre el complejo hecho religioso $k^{\prime} i c h e$ ', ¿habrá que negar la presencia de Cristo en los creyentes de la tradición religiosa maya-quicheana, pasando por alto su hondo sentido

13. Cfr. José Mata Gavidia, Existencio y perduración en el Popol Vuh (Guatcmala, 1950), pp. 104s. 
sagrado, sus sinceras y continuas expresiones cúltico-sacras, comunitarias e individuales?

El Vaticano II dio mucha luz sobre estos problemas. Dice la Lumen gentium (16b y 17) que todos los que sin culpa no conocen de un modo expreso a Cristo y siguen con sinceridad el dictado de la conciencia, cumpliendo con lo verdadero y bueno sembrado en el corazón y en la mente de los adeplos y en los ritos y tradiciones de su religión, pueden alcanzar la salvación elerna. No se deben separar el orden de la creación del orden de la redención, aunque tampoco se pueden confundir entre sí, ni reducir el uno al otro. Dios creador otorgó desde el principio a todos los hombres, sin distinción, los bienes nalurales, depositados en la creación entera y en su criatura racional, el ser humano. Juntamente con estos bienes, le dispensó el llamamiento a la salvación elerna. La voluntad salvífica universal de Dios hubiera sido ilusoria, si no hubiese incluido los medios válidos para su cumplimiento. Sucede la historia del pecado original del primer hombre, y Dios, aunque se apesadumbra de haber creado al ser humano (Gn 6, 6ss) y lo castiga, no se vuelve atrás en su designio salvador; y en Noé salva a la humanidad y nunca más volverá a maldecir la tierta por causa del hombre $(\mathrm{Gn} 8,21)$ : "yo establezco mi alianza con ustedes, y no volverá nunca más a ser aniquilada toda carne por las aguas del diluvio para destruir la lierra" (Gn 9, 11-17).

Aquí se encuentra la promesa de salvación para los humanos que, no perteneciendo al pueblo elegido y a la alianza mosaica, nunca llegan a conocer el plan de la redención de Cristo. Este es el gran secreto, el oculto y profundo misterio de Dios, inaccesible en las generaciones pasadas, sólo revelado hasta que llegó la plenitud de los tiempos, la redención, la salvación de los gentiles (Ef 1,$9 ; 3,3-4)$. El camino de esta salvación de los paganos está trazado sobre los bienes de la creación, que no han sido pervertidos por el pecado y que se hallan sembrados en todo lo verdadero y bueno de sus religiones. Es un camino de salvación legítimo, aunque ordenado al plan de redención de Cristo. Este camino abierto a la salvación eterna no es fácil, como atestigua la Iglesia ( $L G$ $16 \mathrm{~b}$ y 17), por las graves heridas del pecado.

Creado por Dios en la justicia, el hombre, sin embargo, por instigación del demonio, en el propio exordio de la historia, abusó de su libertad, levantándose contra Dios y pretendiendo alcanzar su propio fin al margen de Dios. Conocieron a Dios, pero no lo glorificaron como a Dios. Oscurecieron su estúpido corazón y prefirieron servir a la criatura, no al Creador $(\mathrm{Rm} \mathrm{1,} \mathrm{21-}$ 25; GS 13).

Tampoco es fácil para el creyente. Pero al conocer la fuente de la salvación, la comunidad de Cristo siente la apremiante urgencia de llevar su anuncio. El evangelizador de los k'iche's conoce que la presencia de Jesús se halla con su gracia en las mediaciones opacas de todo lo bueno y verdadero que existe en sus 
mentes $y$ en sus tradiciones religiosas, y que pueden salvarse, y pondera lo difícil que les es vivir rectamente, según su conciencia, para logar la salvación. Por ello, intenta llevarlos al expreso y existencial conocimiento de Cristo, en quien "los gentiles son coherederos, miembros del mismo Cuerpo y partícipes de la misma promesa por del evangelio" (Ef 3,6 ).

La inculturación de la fe y la identificación encarnada de ésla con la cultura no constituyen una alternativa que hay que admitir o rechazar, sino la propuesta de un ideal para alcanzar. Represenlan dos momenlos del proceso de inculluración que, según las circunstancias, exigirá cargar el acento alternativamente en uno o en otro. Dentro de este proceso será decisiva la manera de entender la fe y la cultura para fijar la naturaleza y el nivel de la que deba llevarse a cabo't.

\section{Conclusión}

Al terminar el trabajo sobre el Libro sagrado, uno de los documentos más notables de los aborígenes de América, el Popol Vuh de los maya-k'iche's mesoamericanos, resumamos las conclusiones-propuestas a las que hemos llegado.

Hemos expuesto, dentro del marco de las distintas lecturas hechas hasla el presente, una nueva comprensión de la dimensión religiosa del Libro, valiéndonos de las aportaciones que nos entregan las recientes ciencias de la religión, la fenomenología de la religión, la historia de las religiones, la mitología científica y simbolología religiosa y, en un paso más adelante, la teología de las religiones. Utilizando el instrumental que nos prestan estas ciencias, nos hemos acercado al hecho ético-religioso popolvujiano, escrutando sus complejas y plurales manifestaciones.

Hemos comprobado que es un hecho humano especifico, irreductible a cualquiera otra actividad hominal, cargado, sí, de escoria y ganga lerrena, pero también grávido de nobleza y hondad en las intenciones y en la praxis existencial. Se muestra como un hecho no clausurado en la simple materialidad de un horizonte intramundano, sino abierto a la trascendencia y al misterio. Esta comprobación vierte un raudal de luz sobre el conlenido sacro ético-religioso del Libro para su intelección adecuada y auténtica. En este resultado más global quedan implícitas otras adquisiciones más concrelas.

Dentro del aspecto cultural-religioso se ha logrado, asi lo pensamos, el muy importante esclarecimiento para la autenticidad del texto popolvujiano, de quién fuera el transcriptor de las piclografias originales al idioma $k$ 'iche' hablado, el fraile dominico Alonso de Portillo de Noreña, y del liempo en que se efectuó, que fue entre 1554-1556. Esclarecimiento largamente buscado y que nuestro

14. Robert Schricter, ¿"Inculturación de la fe o idenlificación con la cultura”? Concilium 251 (1994) p. 42. 
experimentado y sapiente asesor, el licenciado Agustín Estrada Monroy, lo juzga decisivo por las pruebas documentales por nosotros aducidas, habiendo sido él el primero que rastreó la dirección apropiada, al tener conocimiento de la existencia de una tradición oral del Consejo de los Principales K'iche 's'.5.

Desde el punto de vista ético y teológico, ambas dimensiones inseparables, conformando una misma realidad, opinamos que la teoría de la presencia de Cristo en las religiones, derivada de la expresión del Vaticano II, "se pueden salvar", a nuesıro parecer, ilumina enteramente la tradición religiosa de los indígenas alteños de Guatemala, como camino legílimo de salvación. Es un camino dispuesto providencialmente por Dios, aunque provisional y difícil de transitar para los aborígenes, "al no poseer los abundanles dones de la redención de Cristo". Pero esta posibilidad salvífica, que es de arduo cumplimiento, por el pecado del hombre, nos remite a la última insistencia en nuestro trabajo de la praxis de una auténtica y permanente inculturación, inaccesible al desaliento, para darles a conocer a los nativos mesoamericanos que lo desconozcan, el evangelio de Jesús y oblengan así los frulos de la salvación (Hch 4, 12).

Mas llegados a este punto, se hace insoslayable una interrogante fundamental. Toda auléntica tradición encierra, tanto en su sentido activo de entregar como en su sentido pasivo de recibir lo entregado, una dinámica que la lanza hacia el futuro. La tradición quicheana, cultural y religiosa, a pesar de la afirmación del último verso del Libro, "Aquí se acabó todo lo que teníamos que narrar, tocante al K'iche', que ahora se llama Santa Cruz" (PV 892), reseña el pasado histórico, mas también ausculta tácitamente la palpitación del presente y se esfuerza en trazar una proyección inarticulada, pero real, hacia el porvenir. Al examinar, en la actualidad, sus dimensiones y valores éticos, surge de inmediato la pregunta que se hacen todos los que se esfuerzan en defender los derechos y los valores humanos y se ven obligados a ser espectadores, en América Latina y en otras diversas partes de la tierra, del ancho universo de tantos conflictos económicos, culturales y políticos, que tienen como sujelos a los aborígenes: Chiapas, Brasil, Ecuador y diversas naciones del continente africano y asiático.

¿Podrán sobrevivir las culturas y Iradiciones autóctonas? ¿Qué quieren y exigen los indígenas en muchas regiones de la tierra que un dia fuera suya y en la que hoy se sienten y se reconocen como extraños? El peligro real no proviene ahora del colonialismo de viejo cuño, sino de una amenaza ya presente, actuante y más dura y resistente, para quebrantarla. A to que aspiran esos numerosos grupos humanos, reivindicando su dignidad, son la liberación del atraso, de la marginación, de la inmensa miseria y de la pobreza en la que vienen viviendo

15. Cfr. A. Morán, Interpretación teológica contextual del Popol Vuh. Una lectura de las diversas dadas hasfa hoy (San Salvador, 20(00). 111, 3, y en Conclusiones, e). Jonde se desarrolla ampliamentc cl tcma. 
desde hace centenares de años. Muchos de esos pueblos no pertenecen al dilatado y salobre desierto de una pobreza irremediable, bastantes de ellos poseen grandes riquezas y abundantes recursos materiales, culturales y humanos de muy diversa índole. Lo que necesitan es que les pongan a su alcance medios y técnicas, para que, saliendo de su incapacidad e imposible postración vigente, en orden a la organización, producción de bienes y administración de los mismo, puedan por sí mismos levantarse y emprender el camino de su propia sabrevivencia y reconstrucción.

Aquí es donde hay que clamar con indignación, la cruel y salvaje indiferencia de todos aquellos que, manteniendo en sus manos los hilos de la riqueza y del poder, pretenden realizar su personal inculturación y redención del mundo indígena, a la medida de sus propios y egoístas intereses. No se quicre escuchar a los mismos aborígenes que, año tras año, reclaman, con toda lógica y verdad, con exactitud y justicia, sus derechos de posesión de sus tierras, que les han sido arrebaladas, el respeto de sus culturas y lenguas y nobles costumbres, la inlegración en la modernidad, porporcionándoles medios para salir de su atraso, aislamiento y marginación, escuelas para la educación con el aniquilamiento de la ignorancia, empleo y Irabajo para desterrar la escasez, pobreza y miseria en las cuales viven inmersos. A eso es a lo que aspiran millones de nativos de muchas y variadas regiones de América, de Africa y Asia. El pronto y efectivo cumplimiento de estos derechos haría inútil e insignificante la promulgación, siempre engañosa, de legislaciones especiales y muy peculiares autonomías, de parte de gobiernos que nunca las llegan a cumplir.

Esto es, restablecerlos en el lugar que les corresponde como seres humanos con la plenitud de sus valores éticos. De lo contrario, tendríamos que llegar al inevitable y lamentabilísimo hecho de la desaparición de un inapreciable caudal de bienes y riqueza de la humanidad, que estas culturas autóctonas representan en nuestro mundo que se precia de civilizado. 